\title{
Teaching Eighteenth-century Poetic Satire with a Competency-based Approach: Jonathan Swift and Lady Mary Wortley Montagu
}

\author{
María Jesús Lorenzo Modia (Corresponding Author) \\ Universidade da Coruña, Facultade de Filoloxía \\ Campus da Zapateira, s/n, A Coruña 15071, Spain \\ Tel: 34-981-167-000 (ext. 1824) E-mail: mlorenzomodia@udc.es \\ Begoña Lasa Álvarez \\ Universidade da Coruña, Facultade de Filoloxía \\ Campus da Zapateira, s/n, A Coruña 15071, Spain \\ Tel: 34-981-167-000_E-mail: begonalasa@udc.es
}

$\begin{array}{ll}\text { Received: November 22, } 2011 & \text { Accepted: November 28, 2011 Published: December 1, } 2011 \\ \text { doi:10.5539/ies.v4n5p25 } & \text { URL: http:/dx.doi.org/10.5539/ies.v4n5p25 }\end{array}$

This paper has been possible thanks to the research project "O papel da muller na prensa inglesa no inicio da idade moderna: Estudo sincrónico e diacrónico” (PGIDT07PXIB212149PR), funded by the Galician Government (Xunta de Galicia). This grant is hereby gratefully acknowledged.

\begin{abstract}
The purpose of this essay is to analyse the teaching of literature with a competency-based approach. This is exemplified by means of a thorough study of a poetic duel between two relevant eighteenth-century writers, Jonathan Swift and Lady Mary Wortley Montagu, and more specifically, by means of the satires entitled respectively "The Lady's Dressing Room" (1732) and "The Reason that Induced Dr S[wift] to write a Poem call'd the Lady's Dressing Room” (1734).
\end{abstract}

Keywords: Jonathan Swift, Lady Mary Wortley Montagu, Competency-based approach, Literature teaching, Eighteenth-century, Satire, Poetry

\section{Introduction}

This paper will analyse the teaching and learning of a poetic duel between Jonathan Swift and Lady Mary Wortley Montagu as a reflection of the satirical writings of the period and their context. It is significant in that their invectives have both literary and cultural implications, particularly in terms of gender roles and social issues. The language used by these writers in their satires deserves a thorough analysis, since it proved to be an outstanding example of coprolalia, a sign of misogyny and misanthropy in the case of Swift, and a defence against abusive sexism on the part of Montagu. Although the main goal of satire is attacking a contrary, its humorous and scatological aspects should not be neglected, as they are well-known teaching strategies, particularly instrumental in poetry. The epistemological stance taken in the analysis of this eighteenth-century instance of poetic satire will be marked by a competency-based foreign language teaching and learning approach (Richards \& Rodgers, 2001). This approach includes not only linguistic competence with the four skills, but also cultural and artistic competence in so far as both of these offer students tools for understanding literature and its history. Likewise, sociolinguistic competence is also pertinent here, as it provides food for thought concerning human rights and gender issues. The competency-based approach proves to be relevant as, it is hoped, it will promote non-discriminatory and respectful usage of language regarding both gender and post-colonial issues. However, in order to make this study more comprehensive, the teaching and learning methodology will be complemented with the use of cultural studies and criticism (Dyer, 1982); neo-historicism (McKeon, Gallagher, \& Greenblatt, 2000); gender studies (Ballaster, 1992; Spencer, 1986; Spender, 1986; Todd, 1989); post-colonial studies (Spivak, 1990, 1993, 1999); and particularly with literature teaching (Lorenzo Modia, 2005; Moskal \& Wooden, 2005; Showalter, 2003). 


\section{Teaching Sessions}

This survey also raises the issue of the lack of centrality of eighteenth-century English poetry in the university curriculum, and challenges the current teaching canon. This task may be accomplished through three different two-hour sessions in class, bearing in mind that our perspective is student-centred, since he or she must play an active role in the process of learning. The first session involves prior close reading of the poems so that students may be familiar with them and their respective authors. In order to do so, a detailed account of the literary context, together with the eighteenth-century meanings of words and phrases are provided for the students to achieve a full perception of the historical period in which they were produced. The second one will be a seminar class, so that they can experience complete immersion in the texts and their con-texts. In the third and last session, they are invited to exploit their interpretive and critical abilities in order to conduct a fruitful discussion about the poems and eventually produce key topics for a further discussion and/or for a future essay. These sessions are organised following the framework of the European Higher Education Area (EHEA), within the Bologna Process, which involves theoretical and practical classes (lectures and seminars, or tutorials). This unit could be used for students reading English (BA in Humanities in general), and it may also be included in the curriculum of Faculties of Education, both in BA and Masters of Education (PGCE, Postgraduate Certificate of Education).

\subsection{First Session. Historical and Literary Context}

The first session will include a general lecture for the whole class in which the teacher tries to immerse the students in the particular atmosphere of the beginning of the eighteenth century in England. The function of the teacher here is understood as a learning facilitator so that undergraduate or graduate students may become fully aware of the context in which these poems were produced. It is within this collaborative relationship between the university lecturer and the students that this first session takes place, and questions and comments are welcomed at the end of the session. As is well known, the so-called Age of Enlightenment may be an especially appealing period for the students. In that period, London was a lively and bustling city where people tended to gather in social, political, and literary circles, in coffee-houses and clubs, and comment on daily matters. It was also a moment of great controversy with outright confrontations between politicians, religious people, or writers. The flourishing of the printing business must be taken into consideration, too, since at this moment the common reader acquired an important role in the success or failure of a given writer, a fact which increasingly depended on the sales of literary works. Poetry, and especially satire, was among the most successful genres among the literati, since it was a reflection of this thriving and controversial atmosphere, and served as a suitable vehicle for voicing the harsh disagreements between antagonists. In this context we have to place both of the authors analysed here. They wrote several satires, but attention will be paid to "The Lady's Dressing Room" (1732) by Jonathan Swift and Lady Mary Wortley Montagu's response, entitled "The Reason that Induced Dr S[wift] to write a Poem call'd the Lady's Dressing Room" (1734). Both Swift and Montagu are two of the most renowned satirists of their time, perhaps only surpassed by Alexander Pope. Pedagogically, the choice of these two writers is groundbreaking since it provides the opposition between a very well-known and famous male writer and a female voice not so glorified in the history of literature. In doing so, the concept of an established literary canon is contested by a more dynamic and comprehensive approach which shows the existent dialogue between authors later considered as belonging to different spheres, thus stating the synchronic fluidity of the canon. Regarding the choice of the literary subgenre, the satire, it must be noted that it has particularly relevant discourse features to be exploited in an undergraduate class, such as its comic and derogatory effects. It is particularly so in the case of the scatological satire due to its sexual references and the unexpected use of colloquial and vulgar terms, and it proves to be attractive for teenagers and young adults.

"The Lady's Dressing Room" is the first of the so-called scatological poems written by Swift during the 1730s, comprising as well "Cassinus and Peter", "Strephon and Chloe", and "A Beautiful Young Nymph Going to Bed". These poems were composed in his old age, when prose seemed to decline in Swift's literary career and poetry was revitalized (McMinn, 2003, p.27). Lady Mary Wortley Montagu's retaliation appeared anonymously in 1734. As the title of the poem states, "The Reason that Induced Dr S[wift] to write a Poem call'd the Lady's Dressing room", it is an instance of what is nowadays known as a prequel to the satirical poem composed by Swift. But Montagu's response was not the only one. The same year of the publication of Swift's poem, in 1732, a poetic composition entitled "The Gentleman's Study, In Answer to [Swift's] The Lady's Dressing Room" by a Miss W--- appeared.

Concerning the satiric genre, several reasons propitiated its increasing development at the beginning of the eighteenth century. A first of them was the great number of verses by Roman satirists, such as Horace, Juvenal, or Martial, which were translated throughout the seventeenth century, and which favoured numerous imitations by British writers; as well as the publication in 1693 of John Dryden's influential essay on satire "Discourse concerning the original and progress of satire", which was decisive in providing a set of rules for composing satires taking the 
Classical Roman authors as examples (Griffin, 1994, pp.18-19). Secondly, the Restoration of King Charles II, being himself used to the French atmosphere of high society, facilitated freedom of speech and more permissiveness. Finally, the rise of the political parties after the Glorious Revolution also produced numerous satirical writings. As Brean Hammond (2006) states, "Satire is the art of holding up to ridicule an individual, or an institution (such as the Church or the government), or a more abstract entity such as the "humankind"' (p.369). Satirists usually write out of discontent and indignation, however, as Ruben Quintero (2007) asserts: "with a sense of moral vocation and with a concern in public interest [...] The satirist, either explicitly or implicitly, tries to sway us toward an ideal alternative, toward a condition of what the satirist believes should be" (pp.1,3). Furthermore, some form of attack or ridicule is required in a text for it to be satiric. Finally, as satire is an urban more than a rural genre, it depends on "intimate knowledge of cliques, clubs, associations, allegiances, slang, trade-talk, gossip" (Hammond, 2006, pp.372-3).

This peculiar duel between Swift and Montagu also allows a cross-curricular approach in the teaching-learning process, since it offers an inclusive perspective of women, as both authors and readers, in a non-male centred literary world. In this regard, it is worth mentioning that Swift has been considered one of the most notorious misogynists of British literature. However, as J. Paul Hunter (2003) has pointed out, Swift's poems "now have become crucial to his rehabilitation among feminist critics because of their shrewd analysis of what social custom and traditional gender roles do to women's identity and self-conception" (p. 235). Moreover, Louise Barnett (2007), who has explored Swift's relationship with women, has shown that in his social life the Irish writer always saw a great number of women and liked them, particularly Esther Johnson -known as Stella, since such was the name used by Swift to refer to her in his poems - and Esther Vanhomrigh -called Vanessa in his texts- (personal name coined by Swift himself): "In these women he found praiseworthy qualities of character and intellect that, he believed, set them apart from the ordinary run of women" (Barnett, 2007, p.5). Likewise, he promoted the literary careers of some Irish women writers, notably Mary Davys, Laetitia Pilkington, Constantia Grierson, and Mary Barber, who were known as the "female senate" or his seraglio (Doody, 2003, pp.106, 108). On the contrary, when he took women in general as the subject of his writings, Swift contemplated them as dangerous and dreadful, in line with the patriarchal vision of the period, because, according to Barnett (2007), they were starting to appropriate some male privileges (pp. 5-7).

Felicity Nussbaum (1984), in an illuminating study on the satires written against women in this period, acknowledges that the amount of texts on this matter is not very relevant in comparison with those about other subjects; however, she underlines "the persistence of the themes and the repetitiveness of the conventions" (p.2). As stated before, several women surpassed the boundaries imposed by patriarchal order and men perceived it as a menace. As a result, "women become a metaphor for all that is threatening and offensive to the society at large" (Nussbaum, 1984, pp.19-20). In this context, satire, in Nussbaum (1984)'s opinion, is a useful rhetorical device which creates a fiction of power (p.3), reassuring men against impotence (p.20). Similarly, Susan Gubar (1986) considers these kinds of satirical poems are inscribed in "a long line of female monsters of biblical and classical origin" (p.137), which evoke men's dread of women, but specifically of women's control and artistry.

Indeed, Swift draws on classical sources in the composition of his satires against women. Particularly, in the case of "The Lady's Dressing Room", he makes an eighteenth-century adaptation of the Roman poet Juvenal's sixth satire. In Nussbaum's (1984) words,

The dressing-room scenes warn men to penetrate the disguises of women in order to protect themselves. Since the boudoir is the site of woman's preparation for attacking and destroying men, to penetrate it is to disarm the woman. The dressing room, however, is also morbidly fascinating, and the boudoir becomes a living metaphor for a woman's mystery. A woman standing before her dressing table is engaged in exploring her sexual and psychic independence as she creates a separate, private, and self-glorified identity. A man's surreptitious entrance into the forbidden territory subverts her independence in the name of destroying vice (p.105).

In terms of what the dressing room symbolizes, at the end of the seventeenth century and the beginning of the eighteenth century, it is considered, in Tita Chico (2005)'s words, as "a site of lasciviousness and secrecy [...], it represented the possibility that women could act independently and selfishly" (p.9). That is the reason why it was utilized by satirists as a subject in their compositions; however, in the second half of the century, the dressing room enters the domestic novel with Samuel Richardson and is transformed into a place where women could educate themselves and develop their role as mothers (Chico, 2005, p.11).

While satire was considered chiefly a male genre (Thomas Kairoff, 2007, pp.276-7), many women writers of this period devoted their talents to it. Lady Mary Wortley Montagu was one of them, and she excelled in the satiric mode. She was able to read Latin and was fascinated by Classical authors and genres, such as epistles, odes, and satires. She wrote innumerable poems, many of them satires, although her social rank and status deterred her from 
publishing them; most of these compositions circulated in manuscripts among social circles. Nevertheless, some of Montagu's poems were published without her approval (Keith, 2003, p.84; Thomas Kairoff, 2001, pp.161-2).

As most scholars have pointed out, a great number of Montagu's poems are the result of a reaction to a stimulus (Backscheider, 2008, p.87; Grundy, 2006, p.184; Keith, 2003, p.82; Thomas Kairoff, 2001, p.162), normally to criticize it. As a woman, she was particularly concerned by the double standard and injustice that governed men's and women's relations. She was particularly vulnerable to these matters, since both in her literary and personal life she was constantly transgressing the boundaries of what was considered adequate for women (Winch, 2004, p.73). Although Isobel Grundy (1999) has mentioned that Montagu expressed in her letters that male criticism on women did not affect her (p.143), she took offence at Swift's satire against women and decided to retaliate by means of the same method, a satiric composition: "The Reason that Induced Dr S[wift] to write a Poem call'd the Lady's Dressing room", employing a title with a popular formula in the period for entitling political pamphlets (Grundy, 1999, p.143, 55n).

As Halsband and Grundy (1993) state, "Lady Mary always disliked Swift" (p.273). She wrote that Swift "was so intoxicated with the love of flattery, he sought it amongst the lowest of the people and the silliest of women, and was never so well pleased with any companions as those that worshipped him while he insulted them" (qtd. in Paston, 2005, p.488). Montagu (1997) also wrote to her daughter, Lady Bute, commenting on people's reputations, that, paradoxically, Swift "who set at defiance all decency, Truth, or Reason, had a croud [sic] of Admirers, and at their Head the virtuous and Ingenious Earl of Orrey, the polite and learned Mr Greville, with a number of Ladies of fine Taste and unblemish'd Characters" (p.451). Moreover, Lady Mary showed to a friend her chamber bowl pictured with the false backs of books by Pope, Swift, and Bolingbroke, saying that this gave her "the satisfaction of shitting on them every day" (qtd. in Grundy, 1999, p.566). This anecdote clearly evokes some of the lines of Swift's poem "The Lady's Dressing Room", and it seems that it has an obvious connection with it.

\subsection{Second Session. Explication de Texte}

Once the students are aware of the historical and literary context in which the poems were produced, in the second session we will proceed to a group reading of the texts in which, on the one hand, it is important to be sure of the meaning of the respective poems in the eighteenth century and the readings made of them at that time, and on the other, it is paramount that a post-modern or contemporary perspective of the poem is also possible. However, due to the strongly gendered divergent opinions present in the poems, it is crucial to revise our viewpoint as readers, namely, either that of a supposedly vituperated woman or the one of a male chauvinistic character. In order to be able to have an informed reading and a well-founded viewpoint, it is important to be able to read the poems closely and to produce a sound explication de texte, in which the students can perceive the different voices in them and their respective roles in the satires. For this purpose, the students are divided into smaller groups, to go through the poems offering their respective readings and contrasting them with those of their peers, and also to those of the teacher, so that the critical capacities of the students may be developed.

One of the best ways to start the seminar could be to pose a simple question such as who the speaker is and what his or her problem is, used by Sandra Gilbert in her classes (qtd. in Showalter, 2003, p.76), since, no matter how simple it may seem, it proves to be very effective for the students' understanding of the poem. Some of the information that was not provided in the first session, concerning the factual elements of the poem, may be offered sparingly in this session, making sure that it helps their respective open readings of the texts, without giving any definitive interpretation. The following are hints to be used in the discussion.

“The Lady's Dressing Room" narrates how Strephon, finding Celia's dressing room empty, sneaks into it and finds out all the elements used by her in her daily toilet. The poem is constructed in such a way that the reader witnesses Strephon's gradual disenchantment with his admired Celia, who in line 3 is a goddess, while later on, at the climatic moment of the poetic composition, Strephon realizes that she shits (line 118). The female protagonist of the poem, Celia, is not physically present, as can be read in the first lines. However, by means of the "strict survey" (line 7) carried out in her dressing room by Strephon, a negative image of Celia emerges and impacts the reader. As Tita Chico (2005) explains, Strephon, in line with the pervading epistemological and empirical thought of the period, acts as a scientist researching or conducting a survey, but, instead of taking the natural world as the field of study, he explores Celia's dressing room (p.144). As a result, despite Celia's absence, every object in the dressing room reminds us of her, and, as we will see, specifically of a part of her body. The poem thus associates the nature of the space to the nature of the woman to whom it belongs.

What facts or data are going to be discovered by Strephon in Celia's dressing room? The narrator is eager to give the readers an "inventory" (line 10): "a dirty smock [...] / Beneath the arm-pits well besmeared" (lines 11-2); "various combs [...] / Filled up with dirt" (line 20-1), that is, a mixture of "Sweat, dandruff, powder, lead and hair" (line 24); 
"A forehead cloth with oil upon't" (line 25); "night-gloves" (line 29) made up by a lapdog's hide and wet by its urine (lines 31-32); "gallipots and vials" (line 33) filled with washes, paste, pomatum, paints, and slops (lines 34-5); "ointments good for scabby chops" (line 36); "a filthy basin" (line 37) with "the scouring of her hands, [...] her teeth and gums" (lines 38, 40); "the towels; / Begummed, bemattered, and beslimed; / With dirt, and sweat, and ear-wax" (line 44); "the handkerchiefs [...] / All varnished o'er with snuff and snot" (lines 49-50); "The stockings [...], / Stained with the moisture of her toes" (lines 51-2); "greasy coifs and pinners reeking" (line 53).

Nevertheless, the element which deserves more lines and more attention is the chest, where Strephon discovers Celia's chamber pot. In this case, Strephon's research is not based only upon sight, but mostly upon two other senses, namely, smell and touch, particularly when he "lifts the lid" (line 81) and when he puts his hands in it (line 94). The discovery of the pot with its "excremental smell" (line 111) marks the climatic moment of the poem and Strephon ends up his "grand survey" (line 115) with the well-known exclamation: "Oh! Celia, Celia, Celia shits!" (line 118).

As Louise Barnett (2007) underlines, Swift "was particularly sensitive to uncleanliness and endlessly critical of feminine cosmetic deception" (pp. 167-8), a fact that is evidently proven in the poem. Generally speaking, in texts about sexual matters in the eighteenth century, bodies were imagined to smell disagreeably, particularly women's genitals (Harvey, 2004, pp. 206, 207), which also places Swift in line with common and popular notions of the period. Swift himself even justified the aim of the poem in an anonymous text in prose entitled "A Modest Defence of a Late Poem by an unknown Author, call'd, The Lady's Dressing-Room" (1732), emphasising the usefulness of the poem (McMinn, 1991, p.148) and stating that he wanted to promote women's cleanliness. He also underlined that "no Poem was ever written with a better Design for the Service of the Sex: Wherein our Author hath observed to a Title, the Precepts of his Master Horace; or, indeed, hath gone very far beyond him, in the Article of Decency" (qtd. in Ballaster, 2006, p.170).

In the last part of the poem or coda, from line 119 onwards, Strephon's reaction to his careful research is the central topic. He cannot think of women without imagining what might be behind, in their dressing room. The poem has also a narrator or speaker who contemplates this fact as a vengeance precisely for Strephon's peeping in Celia's dressing room (line 119) and explicitly declares that: "I pity wretched Strephon, blind / To all the charms of womankind" (lines 129-30). Thanks to the narrator's comments Strephon is portrayed as an inexperienced and naïve man, who does not understand the nature of women as considered by the narrator, a more qualified and skilled man. For this poetic voice, women are like "queen[s] of love [who] rose from stinking ooze" (lines 131-2) and like "gaudy tulips raised from dung", the famous line which closes the poem.

It is obvious that exaggeration is a fundamental ingredient of satire and that these hyperbolic images are to be borne in mind when reading this kind of texts. As happens with Juvenalian satura and its display of paradoxes, hyperboles and striking images, Swift's verses are also full of this kind of rhetorical device, which "ensure[s] that there is always an ironic distance separating the satire from its subject" (Miller, 2005, p.30). Still, in this case, the link established by Swift between women and filth is not only physical but also moral. As stated before, women for Swift are threatening, they construct a deceiving façade by means of make-up, ornaments and dresses. Poems such as this one are thus intended to warn men against women's deception. The narrator or speaker, however, at the end of the poem seems to provide the right interpretation: it does not matter how dirty women's bodies may be, although with a beautiful appearance, since these bodies are also the source of sexual pleasure. The presence of this omniscient voice creates an ambiguous reading of "The Lady's Dressing Room". One wonders if he is reproving women's dishonest and deceptive behaviour or is mocking Strephon and naïve males who idealize women and end up disappointed when they perceive what Swift exposes as their true nature.

In Montagu's poem, both of the protagonists, male and female, are present and interact with one another. As for the male character, it is quite obvious that the man portrayed in the poem is Swift himself. Montague refers to him as the "Doctor" (lines 1 and 30), "Reverend" (line 63), "Priest" (line 68) and "Dean" (line 85). Montagu's gaze is not so detached, and her satirical composition is close to lampoon. There is not a general censure of men's behaviour or activities, but a sharp criticism by means of satire against the male protagonist's attitude, that is, against Swift himself.

The satirical composition narrates how the male character visits a prostitute, "His dearest Betty" (line 6), and wants to impress her with his external appearance. Like Celia in "The Lady's Dressing Room", the reverend in this poem shows off and tries to disguise himself behind striking clothes and ornaments: "The Doctor in a clean strch'd band, / His Golden Snuff box in his hand, / With care his Di'mond Ring displays / And artfull shews its various Rays" (lines 1-4). In this case, he also wishes to call Betty's attention with his creative talents, but in vain, since she only cares for her financial aims and will only receive him in exchange for money. The intercourse proves to be a disaster due to the Doctor's impotence: "The Reverend Lover with surprise / Peeps in her Bubbys, and her Eyes, / And 
kisses both, and trys - and trys." (lines 63-65). The proud Doctor proclaims: "the Fault is not [in] me" (line 69) and puts the blame on Betty and her terrible smell with two lines which evoke clearly Swift's poem: "Your damn'd Close stool so near my Nose, / Your Dirty Smock, and Stinking Toes" (lines 70-71). Consequently, he wants his money back, but Betty, as a conscious businesswoman, will not agree. The disappointed Dean wants revenge and he only thinks about writing: "I'll so describe your dressing room / The very Irish shall not come" (lines 86-87). Betty does not care about it and the poem ends with her ironic and harsh words: "I'm glad you'l write, / You'l furnish paper when I shite" (lines 88-89).

Lady Mary's allusion to the Irish in the poem is worth mentioning, since it might have a double interpretation, which is also a common device in satire. As is known, Swift, despite being Irish, ambitioned a clerical position in England instead of the one he obtained in Ireland as Dean of St. Patrick's Cathedral in Dublin. He was totally disappointed and depressed. He wrote to his friend Charles Ford: "I know not what to say to You. I cannot write in this Country [...] Being in Engd onely renders this Place more hatefull to me [sic], which Habitude would make tolerable" (qtd. in Aykroyd, 2006, p. 93). Swift's rejection of his own homeland was taken by Montagu as a fact against which she addressed her satirical darts, but the verse line might also suggest another relevant assumption of this period, namely, that the Irish were regarded as second-rank citizens in England. Moreover, by putting this statement in the Dean's mouth, an Irishman himself, Montagu was telling the readers that the Irish did consider themselves inferior to the English.

\subsection{Third Session. Interpretation and Conclusion}

In the third session, organized in smaller groups, after the students have grasped the general meaning of the poems, a public reading of the texts by means of role-playing may be suggested. This task would be revealing in terms of their own interpretation of the texts regarding male versus female relationships. Therefore, a subsequent debate could deal with the way in which the male character is played, either as a strong or as a weak man, and on what grounds that is based. The same question could be posed regarding the roles of women. By means of this activity, students perceive what their perspective in this issue is, and how their respective opinions may vary according to the viewpoint adopted. The role of the reader in literature is necessarily active per se, but especially so in the case of satiric obscene poems (Guillén, 1998, p.236), since one of the main objectives is being provocative in all possible senses of the word. This type of poetry is particularly useful from a cross-curricular stance, and it provides an invaluable opportunity for a fruitful transposition to the present day situation of women in society (Fillion, 1981, p.44), for their literary and artistic representation, and how they are seen respectively by male and female eyes. Women and men are not on equal terms in those satiric compositions and that may be one of the key issues for debate (Walker, 2005, p.200). These ideas, together with other possible suggestions on the part of the students ,may be topics for oral debate in class and for future essays, connecting their abilities to internalize issues with their active roles as producers of new discourses that may connect literature and the arts with their present-day experiences and how the status quo may be changed.

\section{References}

Aykroyd, C. (2006). Savage satire. The story of Jonathan Swift. Greensboro, NC: Morgan Reynolds Publishing.

Backscheider, P. R. (2008). Eighteenth-century women poets and their poetry. Inventing agency, inventing genre. Baltimore: The Johns Hopkins University Press.

Ballaster, R. (2006). Jonathan Swift, the "Stella" poems. In C. Gerrard (Ed.). A companion to eighteenth-century poetry. Oxford: Blackwell. pp. 170-183

Barnett, L. (2007). Jonathan Swift in the company of women. Oxford: Oxford University Press.

Chico, T. (2005). Designing women. The dressing room in eighteenth-century English literature and culture. Lewisburg: Bucknell University Press.

Doody, M. A. (2003). Swift and women. In C. Fox (Ed.). The Cambridge companion to Jonathan Swift. Cambridge: Cambridge University Press. pp. 87-111. http://dx.doi.org/10.1017/CCOL0521802474.006

Dyer, G. (1993). Advertising as communication. London : Routledge.

Fillion, B. (1981). Reading as Inquiry: An Approach to Literature Learning. English Journal, 70 (1), 39-45. http://dx.doi.org/10.2307/816161

Gallagher, C., \& Greenblatt, S. (2002). Practising New Historicism. London \& Chicago: University of Chicago Press.

Griffin, D. (1994). Satire. A critical reintroduction. Lexington, KY: The University Press of Kentucky. 
Grundy, I. (1999). Lady Mary Wortley Montagu. Comet of the Enlightenment. Oxford: Oxford University Press.

Grundy, I. (2006). Lady Mary Wortley Montagu, Six Town Eclogues and other poems. In C. Gerrard (Ed.). A companion to eighteenth-century poetry (pp. 184-196). Oxford: Blackwell.

Gubar, S. (1986). The female monster in Augustan satire. In H. Bloom (Ed.). Jonathan Swift. New York \& Philadelphia: Chelsea House. pp. 137-149

Guillén, C. (1998). Múltiples moradas. Ensayo de literatura comparada. Barcelona: Tusquets.

Halsband, R., \& Grundy, I. (Eds.). (1993). Essays and poems and Simplicity, a comedy. By Lady Mary Wortley Montagu. Oxford: Clarendon.

Hammond, B. (2006). Verse satire. In C. Gerrard (Ed.). A companion to eighteenth-century poetry (pp. 369-385). Oxford: Blackwell.

Harvey, K. (2004). Reading sex in the eighteenth century. Bodies and gender in English erotic culture. Cambridge: Cambridge University Press.

Hunter, J. P. (2003). Gulliver's Travels and the later writings. In C. Fox (Ed.). The Cambridge companion to Jonathan Swift. Cambridge: Cambridge University Press. pp. 216-240. http://dx.doi.org/10.1017/CCOL0521802474.013

Keith, J. (2003). Lady Mary Wortley Montagu (1689-1762): Haughty mind, warm blood and the "Demon of Poesie". In S. Prescott, \& D. E. Shuttleton (Eds.). Women and poetry 1660-1750. Basingstoke, Hampshire: Palgrave. pp. 79-87

Lorenzo Modia, M. J. (Ed.). (2005). All in all: A plural view of our teaching and learning. A Coruña: Universidade de A Coruña.

McKeon, M. (2000). Theory of the novel. A historical approach. Baltimore, MD: Johns Hopkins University Press.

McMinn, J. (1991). Jonathan Swift. A literary life. New York: St. Martin's Press.

McMinn, J. (2003). Swift's life. In C. Fox (Ed.). The Cambridge companion to Jonathan Swift. Cambridge: Cambridge University Press. pp. 14-30. http://dx.doi.org/10.1017/CCOL0521802474.002

Miller, P. A. (2005). Introduction. In P. A. Miller (Ed.). Latin verse satire. An anthology and critical reader. London \& New York: Routledge. pp. 1-34

Miss W---. (1990). The Gentleman's Study, In Answer to [Swift's] The Lady's Dressing Room. In R. Lonsdale (Ed.). Eighteenth-century women poets. Oxford \& New York: Oxford University Press. pp. 129-134

Montagu, Lady M. W. (1993). The Reasons that Induced Dr S[wift] to write a Poem call'd the Lady's Dressing Room. In R. Halsband, \& I. Grundy (Eds.). Essays and poems and Simplicity, a comedy. Oxford: Clarendon. pp. 273-276

Montagu, Lady M. W. (1997). Selected letters. I. Grundy (Ed.). Harmondsworth, Middlesex: Penguin.

Nussbaum, F. A. (1984). The brink of all we hate. English satires on women 1660-1750. Kentucky: The University Press of Kentucky.

Paston, G. (2005). Lady Mary Wortley Montagu and her times. London \& New York: G. P. Putnam's Sons, 1907. Elibron Classics Replica Edition.

Quintero, R. (2007). Introduction: Understanding satire. In R. Quintero (Ed.). A companion to satire ancient and modern. Oxford: Blackwell. pp. 1-11.http://dx.doi.org/10.1002/9780470996959.ch1

Richards, J. C., \& Rodgers, T. S. (2001). Approaches and methods in language teaching. (2nd ed.). Cambridge: Cambridge University Press. pp. 141-149. http://dx.doi.org/10.1017/CBO9780511667305

Showalter, E. (2003). Teaching literature. Oxford: Blackwell.

Spencer, J. (1986). The rise of the woman novelist from Aphra Behn to Jane Austen. Oxford: Blackwell.

Spender, D. (1986). Mothers of the novel: 100 good women writers before Jane Austen. London: Pandora Press.

Spivak, G. C. (1990). The post-colonial critic. New York: Routledge.

Spivak, G. C. (1993). Outside in the teaching machine. New York: Routledge.

Spivak, G. C. (1999). A critique of postcolonial reason: Towards a history of the vanishing present. Cambridge, Mass.: Harvard Univeristy Press. 
Swift, J. (1983). The Lady's Dressing Room. In P. Rogers (Ed.). The complete poems. Harmondsworth, Middlesex: Penguin. pp. 448-452

Thomas Kairoff, C. (2001). Eighteenth-century women poets and readers. In J. Sitter (Ed.). Eighteenth-century poetry. Cambridge: Cambridge University Press. pp. 157-176. http://dx.doi.org/10.1017/CCOL0521650909.008

Thomas Kairoff, C. (2007). Gendering satire: Behn to Burney. In R. Quintero (Ed.). A companion to satire ancient and modern. Oxford: Blackwell. pp. 276-292. http://dx.doi.org/10.1002/9780470996959.ch16

Walker, G. L. (2005). Can man be free/and woman be a slave? Teaching eighteenth -and nineteenth-century women writers in intersecting communities. In J. Moskal, \& S. R. Wooden (Eds.). Teaching British women writers 1750-1900. New York: Peter Lang. pp. 190-204

Winch, A. (2004). "The nymph grown Furious, roar'd": Lady Mary Wortley Montagu's response to Jonathan Swift's “The Lady's Dressing Room”. In B. Zangen (Ed.). Misogynism in literature. Any place, any time. Frankfurt: Peter Lang. pp. 71-88 